\title{
Non-fibrous inorganic particles in bronchoalveolar lavage fluid of pottery workers
}

\author{
M Falchi, L Paoletti, S Mariotta, S Giosue, L Guidi, L Biondo, P Scavalli, A Bisetti
}

\begin{abstract}
Aim-To study the actual exposure of pottery workers to silica particles, as their risk of silicosis is potentially high because of the presence of inhalable crystalline silica particles in the workplace.

Methods-Nine pottery workers underwent bronchoalveolar lavage. The recovered fluid was analysed for cytological and mineralogical content by analytical transmission electron microscopy. The data were compared with those obtained from a control group composed of seven patients with sarcoidosis and six patients with haemoptysis.
\end{abstract}

Results-Cytological results showed a similar profile in exposed workers and controls, whereas in patients with sarcoidosis a lymphocytic alveolitis was found. Microanalysis of the particulate identified the presence of silicates, CRSs, and metals. Pottery workers had higher numbers of total particles and CRSs, and had a higher silicate/metal ratio. In five workers, the presence of zirconium silicate was also detected. Patients with sarcoidosis had the lowest number of particles, and an inverted silicate/metal ratio.

Conclusion-Microanalysis by transmission electron microscope can provide useful information to assess occupational exposure to dusts.

\footnotetext{
Department of

Ultrastructures, Istituto Superiore di Sanità, Roma

M Falchi

L Paoletti

L Biondo

Department of

Cardiovascular and

Respiratory Sciences,

University La

Sapienza, C Forlanini

Hospital, Roma

S Mariotta

S Giosue

L Guidi

L Biondo

A Bisetti

SPISSL USL VT/S

Civita Castellana,

Viterbo, Italy

P Scavalli

Correspondence to:

Dr Luigi Paoletti,

Dr Luigi Paoletti,

Ultrastructures, Istituto

Superiore di Sanità, Viale

Superiore di Sanità, Viale
Regina Elena 299, I-00161

Roma, Italy.

Accepted 11 July 1996
} f recommendations from the Americ Conference of Governmental Industrial Hygienists (ACGIH)) $)^{8}$ the limit of $0.05 \mathrm{mg} / \mathrm{m}^{3}$ for airborne inhalable crystaline silica particles in working environments, above which the payment of an insurance premium is provided for exposed workers. The crystalline silica particles are one of the principal components in ceramic and enamel mixtures. On average they constitute $35 \%-38 \%$ of the vitreous china mixture and $22 \%-26 \%$ of enamels.

Civita Castellana is one of the largest Italian industrial areas involved in the production of vitreous china, fire clay, and pottery articles (about $30 \%$ of the total Italian production). In this area the concentration of crystaline silica particles in working environments has been controlled since 1980. Nevertheless, some cases of silicosis are still diagnosed in the people employed in these plants.

To study the exposures of pottery workers in actual working conditions, we compared the mineralogical analysis, by analytical transmission electron microscopy, of the particles found in BAL fluid of nine workers employed in pottery plants in Civita Castellana for more than 10 years, with the mineralogical analysis of the BAL fluid of a control group composed of seven patients with sarcoidosis and six with haemoptysis, none of whom had ever been occupationally exposed to dusts.

\section{Materials and methods}

STUDY POPULATION

The exposed workers were nine male workers (mean (SD) age 51.1 (6.9); three smokers, four ex-smokers, and two non-smokers) employed in the ceramics industry for at least 10 years. They were recruited during a routine check up. Information on smoking and work history was recorded for each subject. Patients were defined as ex-smokers when they had stopped smoking for at least two years. Lung function tests were obtained, and chest $x$ ray films were classified according to International Labour Organisation (ILO) 1980 criteria.

The control group had never been occupationally exposed to dusts. They were: seven housewives (mean (SD) age 50.8 (13), one smoker and six non-smokers) with pulmonary sarcoidosis stage II (all patients were at their first check up and had never been treated for sarcoidosis before; sarcoid granulomas were found by histological examination of the lymph nodes) and six patients with haemoptysis (five men and one woman, mean (SD) age $38.6(9 \cdot 1)$, three smokers, one ex-smoker, and two non-smokers), all with lung function test scores inside the normal range and without abnormalities on chest $x$ ray film. 
Table 1 Characteristics and mineralogical analysis of the nine pottery workers

\begin{tabular}{|c|c|c|c|c|c|c|c|c|c|}
\hline Case & Smoking & Age & $\begin{array}{l}\text { Duration of } \\
\text { work }(y)\end{array}$ & Duty & $x$ ray film ${ }^{*}$ & Lung function & $\begin{array}{l}\text { All particles/ } \\
\text { ml BALfluid }\end{array}$ & $\begin{array}{l}\text { Crystaline } \\
\text { silica particles }\end{array}$ & $\mathrm{SiZr} / \mathrm{ml}$ \\
\hline 1 & no & 39 & 22 & Furnaces & $\mathrm{p}-\mathrm{p} / 1-0$ & Normal & 29923 & 9236 & 0 \\
\hline 2 & ex & 43 & 22 & Furnaces & $\mathrm{p}-\mathrm{s} / 1-0$ & Obstructive & 57000 & 12828 & 1260 \\
\hline 3 & no & 56 & 11 & Furnaces & $\mathrm{p}-\mathrm{p} / \mathrm{l}-1$ & Normal & 130000 & 27300 & 15000 \\
\hline 4 & yes & 46 & 16 & $\begin{array}{l}\text { Furnaces or } \\
\text { spraying }\end{array}$ & $\mathrm{p}-\mathrm{s} / 1-0$ & Normal & 183827 & 70809 & 36100 \\
\hline 5 & ex & 59 & 22 & Furnaces & $\mathrm{p}-\mathrm{s} / 2-1$ & Normal & 192762 & 39570 & 0 \\
\hline 6 & ex & 58 & 20 & Furnaces & $\mathrm{p}-\mathrm{s} / 1-2$ & Normal & 199936 & 19360 & 0 \\
\hline 7 & ex & 53 & 16 & Blunging & $\mathrm{p}-\mathrm{p} / 1-0$ & Normal & 43440 & 13028 & 0 \\
\hline 9 & yes & 54 & 15 & Decorator & $\mathrm{p}-\mathrm{p} / 1-1$ & Normal & 54183 & 12442 & 829 \\
\hline
\end{tabular}

${ }^{\star}$ Chest $x$ ray film according to ILO classification.

All patients underwent fibroptic bronchoscopy and BAL as part of the diagnostic procedure. Written informed consent was obtained from all subjects.

FIBREOPTIC BRONCHOSCOPY AND BAL

Fibreoptic bronchoscopy was carried out 30 minutes after intramuscular administration of atropine $(0.5 \mathrm{mg})$ and clorpromazine $(50 \mathrm{mg})$. Local anaesthesia was with $0.4 \%$ oxibuprocaine. The BAL was performed in the middle lobe. The fibroscope was wedged in the selected subsegmental bronchus, and five $20 \mathrm{ml}$ boluses of sterile saline solution heated to $37^{\circ} \mathrm{C}$ were injected and immediately withdrawn by mechanical suction.

BAL FLUID PROCESSING AND ANALYSIS

The first aliquot of the BAL fluid was discarded, the other four aliquots were pooled. The fluid was filtered through gauze and the recovered amount recorded. Total and differential cell counts were performed with a Burker haemocytometer and cytocentrifuge preparations were stained with MayGrunwald-Giemsa. At least 300 cells were identified by microscopic examination $(\times 1000)$. Twenty five millilitres of BAL fluid were used for mineral particle analysis by transmission electron microscope. The BAL fluid samples were put in polyethylene containers with $10 \mathrm{ml} 5 \%$ ultrapure sodium hypochlorite (Aldrich-Chemie) and, if necessary, $10 \mathrm{ml} 30 \%$ hydrogen peroxide. The containers were kept at $30^{\circ} \mathrm{C}$ for between 30 minutes and one hour, until complete oxida- tion of the organic fraction. The resulting solution was diluted with deionised water and then filtered through cellulose nitrate filters (25 mm diameter) with a pore size of $0.45 \mu \mathrm{m}$ (Sartorius AG, Goettingen-Germany). The filter surfaces were lightly smoothed by a plasma etching before use. Then the filters were dried, covered with a thin carbon film, cut, mounted on standard 200 mesh copper grids for transmission electron microscope, and exposed to acetone fumes until the filter dissolved. All the reagents and the solutions used for sample preparation were prefiltered to avoid contamination with particles. Also, two blank samples were processed in the same manner as BAL samples in different phases of the study and analysed; no mineral particles were found in either sample.

The mineral particulate on carbon films was analysed by a transmission electron microscope Philips EM430 equipped with an EDAX energy dispersive spectrometer for microanalysis of $x$ ray films. For each subject 25 to 40 grid apertures (an aperture effective area being about $8400 \mu \mathrm{m}^{2}$ ) were examined in at least five different grids; an accelerating voltage of $250 \mathrm{kV}$ and a magnification of $\times 10000$ were used. The particles detected were identified by morphology, chemical composition (elements with atomic number $>11$ ), and crystalline structure. The detected particles were grouped as three types-namely, $(a)$ silicates (particles containing silica), (b) crystaline silica particles (particles which showed an EDAX spectrum composed only of a $\mathrm{Si}$ peak and with a diffraction pattern indicative

Table 2 Characteristics and mineralogical analysis of the patients with sarcoidosis

\begin{tabular}{llllllll}
\hline Case & Sex & Age & Smoking & fob & $\begin{array}{l}\text { All particles) } \\
\text { ml BALfluid }\end{array}$ & $\begin{array}{l}\text { Crystaline } \\
\text { silica particles }\end{array}$ & Silicates (\%) \\
\hline 1 & F & 76 & no & Housewife & 6409 & 1780 & 28 \\
2 & F & 55 & no & Housewife & 13190 & 4770 & 36 \\
3 & F & 45 & no & Housewife & 14771 & 5339 & 36 \\
4 & F & 37 & yes & Housewife & 15872 & 7143 & 45 \\
5 & F & 49 & no & Housewife & 17489 & 7027 & 40 \\
6 & F & 39 & no & Housewife & 20326 & 6911 & 34 \\
7 & & no & Housewife & 38650 & 3632 & 30 \\
\hline
\end{tabular}

Table 3 Characteristics and mineralogical analysis of the patients with haemoptysis

\begin{tabular}{llllllll}
\hline Case & Sex & Age & Smoking & fob & $\begin{array}{l}\text { All particles/ } \\
\text { ml BALfluid }\end{array}$ & $\begin{array}{l}\text { Crystaline } \\
\text { silica particles }\end{array}$ & Silicates (\%) \\
\hline 1 & M & 36 & yes & Employee & 18202 & 2844 & 69 \\
2 & M & 57 & yes & Worker & 29048 & 4968 & 62 \\
3 & M & 34 & ex & Worker & 50461 & 4266 & 47 \\
4 & M & 47 & yes & Employee & 64780 & 6320 & 50 \\
5 & M & 24 & no & Nurse & $\mathbf{4 5 5 0 4}$ & 3318 & 43 \\
6 & 26 & no & Nurse & 14647 & 1185 & 63 \\
\hline
\end{tabular}


Table 4 Mean (SD) cytological and mineralogical findings of $B A L$ fluid analysis

\begin{tabular}{|c|c|c|c|c|c|c|}
\hline & $\begin{array}{l}\text { Recovery } \\
(\%)\end{array}$ & $\begin{array}{l}\text { Cells/ml } \\
\left(\times 10^{4}\right)\end{array}$ & $\begin{array}{l}M A C \\
(\%)\end{array}$ & $\begin{array}{l}\text { Lymphocytes } \\
(\%)\end{array}$ & $\begin{array}{l}\text { Neutrophils } \\
(\%)\end{array}$ & $\begin{array}{l}\text { Eosinophils } \\
(\%)\end{array}$ \\
\hline $\begin{array}{l}\text { Patients with } \\
\text { haemoptysis } \\
\text { Patients with }\end{array}$ & $60 \cdot 8(6 \cdot 8)$ & $191 \cdot 6(5 \cdot 7)$ & $89 \cdot 5(5 \cdot 7)$ & $7 \cdot 1(3 \cdot 9)$ & $3.4(3.5)$ & 0 \\
\hline $\begin{array}{l}\text { sarcoidosis } \\
\text { Pottery workers }\end{array}$ & $\begin{array}{l}55 \cdot 1(5 \cdot 7) \\
49 \cdot 2(10 \cdot 6)\end{array}$ & $\begin{array}{l}287 \cdot 4(140) \\
295(202)\end{array}$ & $\begin{array}{l}65 \cdot 8^{\star \star \star}(9 \cdot 8) \ddagger \ddagger \ddagger \\
91 \cdot 8(4 \cdot 9)\end{array}$ & $\begin{array}{l}30 \cdot 7^{\star \star}(11) \neq \ddagger \\
6 \cdot 6(4 \cdot 5)\end{array}$ & $\begin{array}{l}3 \cdot 5(5 \cdot 5) \\
1(0 \cdot 7)\end{array}$ & $\begin{array}{l}0 \\
0 \cdot 2(0 \cdot 4)\end{array}$ \\
\hline
\end{tabular}

$\star \mathrm{P}<0.05, \star \star \mathrm{P}<0.01, \star \star \star \mathrm{P}<0.001$, haemoptysis $v$ sarcoidosis;
$\ddagger \mathrm{P}<0.05, \quad \neq \ddagger \mathrm{P}<0.01, \quad \neq \neq \neq \mathrm{P}<0.001$, sarcoidosis $v$ pottery workers.

of a crystalline structure; amorphous silica particles were pooled in the silicates group), (c) metal particles and particles containing different elements from silicon.

\section{STATISTICAL ANALYSIS}

Statistical analysis was performed by MannWhitney $U$ test in the evaluation of cytological and mineralogical data. The $\chi^{2}$ test was used to analyse the silicate and metal patterns, and the frequency of metal compounds. A P value $<0.05$ was considered to be significant.

\section{Results}

Tables 1 to 3 show the characteristics of the exposed and control subjects. In all pottery workers chest $x$ ray films showed small opacities classified in categories 1 and 2 of the ILO classification, typical of pneumoconoises. Six subjects worked on the furnaces, one in blunging, one in enamelling, and one in decoration. All of them had normal lung function tests except for one, who presented an obstructive pattern. The number of particles $/ \mathrm{ml}(\mathrm{pp} / \mathrm{ml})$ varied from 29923 to 199936 , and crystaline silica particles $/ \mathrm{ml}$ ranged from 9236 to 70890 . A distinctive characteristic of five exposed subjects was the presence of zirconium silicate particles.

Table 4 shows the results of cytological and mineralogical analysis of BAL fluid. The percentage of BAL fluid recovered from pottery workers was significantly lower $(P<0.05)$ than in patients with haemoptysis, although the total cell count $/ \mathrm{ml}$ did not show significant differences between groups.

Significant differences between groups were found in particle concentrations in BAL fluid. Occupational exposure of pottery workers is reflected by the average particle concentration which is about one order of magnitude greater

Table 5 Frequency of the elements detected among the metal particles

\begin{tabular}{lccc}
\hline & $\begin{array}{l}\text { Patients with } \\
\text { haemoptysis }\end{array}$ & $\begin{array}{l}\text { Patients with } \\
\text { sarcoidosis }\end{array}$ & $\begin{array}{l}\text { Pottery } \\
\text { workers }\end{array}$ \\
\hline $\mathrm{Ca}$ & $21 \cdot 4(100)$ & $17 \cdot 2(87)$ & $38 \cdot 3(87)$ \\
$\mathrm{Fe}$ & $7 \cdot 5(100)$ & $27 \cdot 7(100)$ & $10 \cdot 5(89)$ \\
$\mathrm{Ti}$ & $23 \cdot 8(100)$ & $36 \cdot 6(100)$ & $16 \cdot 7(100)$ \\
Others & $26 \cdot 8(83)$ & $8 \cdot 6(86)$ & $11 \cdot 8(89)$ \\
$\mathrm{Al}$ & $2 \cdot 5(83)$ & $1 \cdot 3(57)$ & $4 \cdot 3(67)$ \\
$\mathrm{Zn}$ & $12 \cdot 9(83)$ & $5 \cdot 5(57)$ & $15 \cdot 5(33)$ \\
$\mathrm{FeCrNi}$ & $0 \cdot 9(16)$ & $1 \cdot 6(57)$ & $1 \cdot 4(33)$ \\
$\mathrm{SBa}$ & $3 \cdot 2(33)$ & $0 \cdot 2(14)$ & $0 \cdot 5(22)$ \\
$\mathrm{Ni}$ & $0 \cdot 8(16)$ & $0 \cdot 4(28)$ & $0 \cdot 9(33)$ \\
$\mathrm{Pb}$ & $0 \cdot 2(66)$ & $0 \cdot 9(28)$ & $0 \cdot 5(22)$ \\
Total metal particles & & & \\
detected (n) & 106415 & 82086 & 250551 \\
\hline
\end{tabular}

Data are expressed as \% particles containing the element/total number of metal particles. In parentheses, \% subjects in whom the element was found. than in the control group (patients with sarcoidosis $(P<0.001)$ and patients with haemoptysis $(P \sim 0.05))$.

As expected, the highest concentration of crystaline silica particles was obtained from pottery workers, and the relative difference from the other groups was significant $(P<0.001)$.

Differences among groups were also evident when comparing the average composition of the mineral particulate recovered in BAL fluid. Patients with haemoptysis showed an average frequency of metal, silicates, and crystaline silica particles comparable with those of nonexposed subjects as measured in previous studies. ${ }^{9-11}$ Patients with sarcoidosis showed a higher percentage of metal particles than did patients with haemoptysis. The exposed group showed an inverted ratio of silicates/metal particles and an average frequency of $23.6 \%$ of crystaline silica particles.

In the metal particles group, the nine most frequent elements identified were: $\mathrm{Al}, \mathrm{Ca}, \mathrm{Fe}$, $\mathrm{FeCrNi}$ alloys, $\mathrm{Ni}, \mathrm{Pb}, \mathrm{SBa}, \mathrm{Ti}, \mathrm{Zn}$, and other particles containing Fe. Table 5 shows the relative frequency of elements detected in each group, and the percentage of subjects in whom the element was found. Particles containing $\mathrm{Ti}$ were detected in all subjects, $\mathrm{Fe}$ in all except one, and $\mathrm{Ca}$ in all except two. Aluminium and $\mathrm{Zn}$ were present in more than $50 \%$ of $\mathrm{BAL}$ fluids, and $\mathrm{FeCrNi}$ alloys, $\mathrm{SBa}, \mathrm{Ni}$, and $\mathrm{Pb}$ were rare. The differences in the frequency of elements in the groups were affected by the total amount of metal particles detected in each group. For instance, the high percentage of Ti detected in patients with sarcoidosis can be ascribed to the low number of particles detected in all, rather than to a specific type of exposure. Nevertheless, the frequency pattern of pottery workers resembles that of patients with haemoptysis but differs from that of patients with sarcoidosis.

\section{Discussion}

The aim of this study was to evaluate the actual exposure of a group of pottery workers to silica particles. The mineralogical analysis of BAL fluid is used as an adjuvant for the measurement of occupational exposure in patients with interstitial lung diseases. ${ }^{12} 18$ In the past, silica particles were identified by polarised light microscopy. Nowadays, scanning and transmission electron microscopy have considerably improved diagnosis by the identification and semiquantitative microanalysis of silica and other minerals in BAL fluid and bioptic specimens. ${ }^{316}$ Many studies 
Table 4 continued

\begin{tabular}{|c|c|c|c|c|c|}
\hline & $\begin{array}{l}\text { All particles/ } \\
\mathrm{ml}\end{array}$ & $\begin{array}{l}\text { Crystaline } \\
\text { silica particles/ml }\end{array}$ & $\begin{array}{l}\text { Silicone } \\
(\%)\end{array}$ & $\begin{array}{l}\text { Crystaline } \\
\text { silica particles }\end{array}$ & $\begin{array}{l}\text { Metal } \\
\text { particles }\end{array}$ \\
\hline $\begin{array}{l}\text { Patients with } \\
\text { haemoptysis } \\
\text { Patients with }\end{array}$ & 37107 (19705) & $3816(1784)$ & $41 \cdot 9(7)$ & $11(4)$ & $44 \cdot 1(10)$ \\
\hline $\begin{array}{l}\text { sarcoidosis } \\
\text { Pottery workers }\end{array}$ & $\begin{array}{l}18073(9970) \\
111900 \dagger(67018) \mathrm{t十} \text { 㧊 }\end{array}$ & $\begin{array}{l}1472^{\star}(1264) \\
25173(19535) \mathrm{t}+\text { 抹 }\end{array}$ & $\begin{array}{l}27 \cdot 5^{\star \star}(6) \\
56 \cdot 2 \dagger+†(15) \ddagger \ddagger \ddagger\end{array}$ & $\begin{array}{c}8 \cdot 1(5) \\
23 \cdot 6 \dagger+(8) \ddagger \ddagger \ddagger\end{array}$ & $\begin{array}{l}64 \cdot 4^{\star \star}(5) \\
20 \cdot 2+†(17) \neq \neq \ddagger\end{array}$ \\
\hline
\end{tabular}

have investigated the relations between exposure, retained dose, and pathological alteration in subjects exposed to different kinds of dust. ${ }^{517-20}$

Christman et $\mathrm{al}^{2}$ found in the macrophages of granite workers a notable increase in particles with a spectrum of $x$ ray film energies consistent with quartz, and a variety of aluminum, magnesium, and calcium silicate particles. There was a connection between the number of particles and the time of exposure: the pattern was obviously different from healthy controls. Funahashi et al ${ }^{21}$ studied the content of silica particles in the lungs of exposed and unexposed subjects by energy dispersive $x$ ray film analysis and came to the conclusion that the lungs with abnormalities on $x$ ray film consistent with silicosis had an amount of silica, expressed as $\mathrm{Si} / \mathrm{S}$ (silicon/sulphur) ratio, higher than unexposed subjects without abnormal $x$ ray films. Also Lusuardi et $a l^{3}$ found a higher $\mathrm{Si} / \mathrm{S}$ ratio in exposed subjects than in controls and patients with interstitial lung diseases. Bernstein et $a l^{7}$ found a high burden of working substances in the BAL fluid of dental technicians, and came to the conclusion that results from analysis of BAL fluid reflect actual exposure in the workplace.

Our data confirm that it is possible to define the occupational exposure of subjects by the analysis of BAL fluid. The concentration of total particles in BAL fluid seems to be the best indicator of occupational exposure. The mineralogical pattern can give further information on the type of mineral particle pollution to which patients have been exposed. Gaudichet et al $^{22}$ asserted that, in the case of ubiquitous particles, it is necessary to support the evidence of occupational exposure with a quantitative microanalysis of BAL fluid.

The mineralogical particulate pattern in BAL fluid from our unexposed subjects reflects the composition of aerosol particulate found in an urban atmosphere ${ }^{9}$ and BAL fluid particulate concentrations seem to be confined within the range $0 \cdot 1-1 \times 10^{5} \mathrm{pp} / \mathrm{ml}$. Cytological examination showed a similar pattern in normal and exposed subjects, although patients with sarcoidosis showed classic lymphocitic alveolitis. The lowest mineral particle concentrations found in the group with sarcoidosis could be related not only to differences in cytological pattern but also to the fact that this group was made up of housewives, all non-smokers except one (six to seven cigarettes/day); all of them lived in modern urban flats with central heating and gas kitchens and were probably exposed to few breathable mineral particulates.
In non-occupationally exposed people different variables - that is, smoke, work history, passive smoking, residence, hobbies, etcinteract to determine the mineral particulate burden deep in the lungs, whereas quality and quantity of mineral particles in BAL fluid of pottery workers is determined principally by occupational exposure. Silicosis is the result of a chronic exposure (20-40 years) to a high airborne breathable concentration of crystalline silica particles (three to fivefold higher than the threshold limit value $)^{23}$ and it has been shown that crystaline silica particles cause an immune response in the alveolar spaces, involving macrophages and lymphocites, that results in pulmonary fibrosis. ${ }^{12425}$ The presence of significant quantities of crystalline silica particles found in BAL fluid of pottery workers, may be related to the slight pathological alterations indicative of early stages of pneumoconioses.

The presence of zirconium particles in exposed patients deserves some consideration. Zirconium sand, mainly produced in Australia, is used as an opacifier, and typically accounts for $4 \%-12 \%$ of the enamelling mixture. Zirconium silicates are not present in Italian geological formations and, their commercial or industrial uses are mainly confined to foundries and the ceramics industry. Therefore the presence of zirconium silicates in BAL fluid could be used as a marker for the definition of occupational exposure in these specific activities. Liippo et $a l^{26}$ have recently published a case report of hypersensitivity pneumonitis in a ceramic tile worker, attributed to exposure to zirconium silicate, but the data available now are insufficient to hypothesise a causal relation between exposure to zirconium and pulmonary fibrotic reaction. Further investigations should be conducted to explore the possibility of an addictive or sinergic action of crystalline silica particles and zirconium silicate particles in the development of the fibrogenic response of lung tissues.

1 Davis SG. Pathogenesis of silicosis: current concepts and hypotheses. Lung 1986;164:139-54.

Christman WJ, Emerson JR, Graham GBW, Davis SG. Mineral dust and cell recovery from the bronchoalveolar lavage of healthy Vermont granite workers. Am Rev Respir Dis 1985;132:393-9.

3 Lusuardi M, Capelli A, Donner CF, Capelli O, Velluti G. Semiquantitative $x$ ray microanalysis of bronchoalveolar lavage samples from silica-exposed and nonexposed subjects. Eur Respir f 1992;5:798-803.

4 Nugent MK, Dodson FR, Idell S, Deviliar RJ. The utility of bronchoalveolar lavage and transbronchial lung biopsy cumbined with energy-dispersive $x$ ray analysis in the diagnosis of silicosis. Am Rev Respir Dis 1989;140: $1438-41$.

5 Christman JW, Emerson RJ, Hemenway DR, Graham WGB, Davis GS. Effects of work exposure, retirement 
and smoking on bronchoalveolar lavage measurements of lung dust in Vermont granite workers. Am Rev Respir Dis 1991;144:1307-13.

6 Begin RO, Cantin AM, Boileau RD, Bisson GY. Spectrum of alveolitis in quartz-exposed human subjects. Chest 1987;92:1061-7.

7 Bernstein M, Pairon JC, Morabia A, Gaudichet A, Janson $X$, Brochard P. Non-fibrous dust load and smoking in dental technicians: a study using bronchoalveolar lavage. Occup Environ Med 1994;51:23-7.

8 American Conference of Governmental Industrial Hygienists. Documentation of the threshold limit values and biological exposures indices, 5th ed. Cincinnati, US: ACGIH, 1986.

9 Falchi M, Donelli G, Paoletti L. Influence of particle size and chemical composition on efficiency of clearance mechanisms: electron microscopy studies in humans. Environ Health Perspect 1994;102:241-3.

10 Falchi M, Biondo L, Conti C, Cipri A, De Marinis F, Gigli B, Paoletti L. Inorganic particles in BAL fluids from nonoccupationally exposed subjects. Arch Environ Health 1996;51:157-61.

11 Chariot P, Couste B, Guillon F, Gaudichet A, Bignon J, Brochard $P$. Non fibrous mineral particles in bronchoalveolar lavage fluid and lung parenchyma from the general population. Am Rev Respir Dis 1992;146:61-5.

12 De Vuyst P, Van de Weyer R, De Coster A, Marchandise FX, Dumortier P, Ketelbant P, Jedwab J, Yernault JC. Dental technician's pneumoconiosis. Am Rev Respir Dis 1986;133:316-20.

13 Johnson NF, Haslam PL, Dewar A, Newman-Taylor AJ, Turner-Warwick $M$. Identification of inorganic dust particles in bronchoalveolar lavage macrophages by energy dispersive $x$ ray microanalysis. Archiv Environ Health dispersive $x$ ray

14 European Society of Pneumology Task Group on BAL. Technical recommendations and guidelines for bronchoalveolar lavage (BAL). Eur Respir f 1989;2:561-85.

15 Pairon JC, Roos F, Iwatsubo Y, Janson X, Brochard P Lung retention of cerium in humans. Occup Environ Med 1994;51:195-9.

16 Dumortier P, De Vuyst P, Yernault JC. Non-fibrous inor- ganic particles in human bronchoalveolar lavage fluids. Scann Microscop 1989;3:1207-18.

17 Dodson RF, Garcia JGN, O'Sullivan M, Corn C, Levin JL, Griffith DE, Kronenberg RS. The usefulness of bronchoalveolar lavage in identifying past occupational exposure to asbestos: a light and electron microscopy study. Am F Ind Med 1991;19:619-28.

18 Tuomi T, Oksa P, Antilla S, Taikina-aho O, Taskinen E, Karjalainen A, Tukiainen P. Fibres and asbestos bodies in bronchoalveolar lavage fluids of asbestos sprayers. $\mathrm{Br} \mathcal{F}$ Ind Med 1992;49:480-5.

19 Teschler H, Konietzko N, Schonfeld B, Ramin C, Schraps $T$, Costabel U. Distribution of asbestos bodies in the human lung as determined by bronchoalveolar lavage: Am Rev Respir Dis 1993;147:1212-5.

20 Teschesler H, Friedrichs KH, Hoheisel GB, Wick G, Soltner U, Thompson AB, Konietzko N, Costabel U. Asbestos fibers in bronchoalveolar lavage and lung tissue of farmer asbestos workers. Am $\mathcal{F}$ Respir Crit Care Med of farmer asbest

21 Funahashi A, Schlueter DP, Pintar K, Siegesmund AK. Value in situ elemental microanalysis in the histologic diagnosis of silicosis. Chest 1984;85:506-9.

22 Gaudichet A, Pairon JC, Malandain O, Couste B, Brochard P, Bignon J. Etude mineralogique des particules non fibreuses du liquide de ravage broncho-alveolaire. Rev Mal Respir 1987;4:237-43.

23 Ziskind M, Jones RN, Weill H. State of the art. Silicosis. Am Rev Respir Dis 1976;113:643-65.

24 Lusuardi M, Capelli A, Carli S, Donner CF. Inflammatory and immune reactions associated with inorganic dust exposure: comparison between patients with and without cxposure: comparison between patients with and with

25 Rom NW, Bitterman BP, Rennard IS, Cantin A, Crystal GR. Characterization of lower respiratory tract inflammation of nonsmoking individuals with interstitial lung disease associated with chronic inhalation of inorganic dusts. Am Rev Respir Dis 1987;136:1429-34.

26 Lippo KK, Anttila SL, Taikina-Aho O, Ruokonen E-L, Toivonen ST, Tuomi T. Hypersensitivity pneumonitis and exposure to zirconium silicate in a young ceramic tile worker. Am Rev Respir Dis 1993;148:1089-92.

\section{Occupational and Environmental Medicine and the electronic age}

OEM has an Email address which is 100632.3615@compuserve.com.We welcome contact by Email, including letters to the editor. Some of our reviewers already send us their reports by Email, helping to speed up the peer review process.

We are moving towards electronic publishing and for some months now we have been asking authors to send us their revised papers on disk as well as a hard copy. I am delighted to report that nearly all our authors are managing to comply with this request; far more than for other specialist journals in the BMJ Publishing group. Oddly enough, the few authors who have not sent us a disk version of their revised papers have been almost exclusively from the United Kingdom. I would be interested in suggestions for why this might be. Perhaps United Kingdom based authors read our correspondence and instructions less assiduously? Watch for revised Instructions to Authors.

The Editor 